University of Nebraska - Lincoln

DigitalCommons@University of Nebraska - Lincoln

2012

\title{
Effects of feeding modified distillers grains plus solubles on marbling attributes, proximate composition and fatty acid profile of beef
}

\author{
A.S. Mello Jr. \\ University of Nebraska-Lincoln \\ B.E. Jenschke \\ University of Nebraska-Lincoln \\ Lasika S. Senaratne \\ University of Nebraska-Lincoln, lasika_ss@yahoo.com \\ Timothy P. Carr \\ University of Nebraska-Lincoln, tcarr2@unl.edu \\ Galen E. Erickson \\ University of Nebraska-Lincoln, gerickson4@unl.edu \\ See next page for additional authors \\ Follow this and additional works at: https://digitalcommons.unl.edu/animalscifacpub \\ Part of the Animal Sciences Commons
}

Mello, A.S. Jr.; Jenschke, B.E.; Senaratne, Lasika S.; Carr, Timothy P.; Erickson, Galen E.; and Calkins, Chris R., "Effects of feeding modified distillers grains plus solubles on marbling attributes, proximate composition and fatty acid profile of beef" (2012). Faculty Papers and Publications in Animal Science.

784.

https://digitalcommons.unl.edu/animalscifacpub/784

This Article is brought to you for free and open access by the Animal Science Department at DigitalCommons@University of Nebraska - Lincoln. It has been accepted for inclusion in Faculty Papers and Publications in Animal Science by an authorized administrator of DigitalCommons@University of Nebraska - Lincoln. 


\section{Authors}

A.S. Mello Jr., B.E. Jenschke, Lasika S. Senaratne, Timothy P. Carr, Galen E. Erickson, and Chris R. Calkins 


\section{JOURNAL OF ANIMAL SCIENCE}

The Premier Journal and Leading Source of New Knowledge and Perspective in Animal Science

\section{Effects of feeding modified distillers grains plus solubles on marbling attributes,} proximate composition and fatty acid profile of beef

A.S. Mello, Jr., B.E. Jenschke, L.S. Senaratne, T.P. Carr, G.E. Erickson and C.R. Calkins

J ANIM SCI published online August 2, 2012

The online version of this article, along with updated information and services, is located on the World Wide Web at:

http://jas.fass.org/content/early/2012/08/01/jas.2010-3240

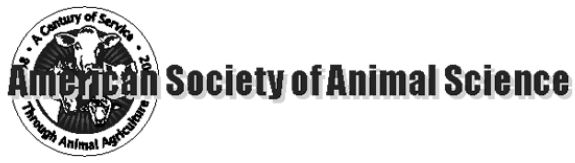

wWw.asas.org 
Running Head: Feeding modified wet distillers grains.

Effects of feeding modified distillers grains plus solubles on marbling attributes, proximate composition and fatty acid profile of beef ${ }^{1,2}$.

A.S. Mello, Jr. ${ }^{\dagger 3}$, B.E. Jenschke ${ }^{\dagger}$, L.S. Senaratne ${ }^{\dagger}$, T.P. Carrł, G.E. Erickson ${ }^{\dagger}$, and C.R. Calkins ${ }^{\dagger 4}$

${ }^{\dagger}$ University of Nebraska, Department of Animal Science and $\ddagger$ Department of Nutrition and Health Sciences, Lincoln, NE 68583-0908

${ }^{1}$ A contribution of the University of Nebraska Agricultural Research Division.

${ }^{2}$ This project was funded in part by the Beef Checkoff.

${ }^{3}$ CAPES / Fulbright - Brazil.

${ }^{4}$ Corresponding author: ccalkins1@unl.edu (Chris R. Calkins). 


\section{ABSTRACT}

Wet distillers grains contain approximately 65\% moisture. A partially dried product (modified distillers grains plus solubles; MDGS) contains about 50\% moisture. However, both have similar nutrient composition on a dry matter basis. The objective of this study was to investigate the effects of finishing diets varying in concentration of MDGS on marbling attributes, proximate composition, and fatty acid profile of beef. Yearling steers $(n=268)$ were randomly allotted to 36 pens which were assigned randomly to 0, 10, 20, 30, 40 and 50\% MDGS (DM basis) and fed for $176 \mathrm{~d}$ prior harvest. Forty-eight h postmortem marbling score, marbling texture, and marbling distribution were assessed by a USDA grader and one ribeye slice (longissimus thoracis) $7 \mathrm{~mm}$ thick was collected from each carcass for proximate and fatty acid analysis. Treatments did not significantly alter marbling score or marbling distribution $(P \leq$ 0.05). USDA Choice slices had coarser marbling texture when compared to USDA Select. Although dietary treatment affected marbling texture no consistent pattern was evident. Diets did not influence fat content, moisture, or ash of the ribeye $(P \geq 0.05)$. For treatments $0,10,30,40$ and $50 \%$ there were positive linear relationships between marbling score and fat percentage in the ribeye $(P \leq 0.05)$ and all slopes were similar $(P=0.45)$. Feeding MDGS linearly increased stearic, linoelaidic, linoleic, linolenic, PUFA and n-6 fatty acids. As levels of MDGS increased, linear decreases were observed in all n- 7 fatty acids and cubic relationships were detected for the 18:1 trans isomers (trans-6-8-Octadecenoic acid, 6-8t, elaidic acid, 9t, trans-10-Octadecenoic acid, 10t, and trans vaccenic, 11t). No effects were observed for saturated fatty acids containing 6 to 14 carbons. Feeding MDGS resulted in increased PUFA, trans, and Omega 6 fatty acids, minimal effects on marbling texture, and no effects on the relationship of marbling to intramuscular fat content relationship. 
Key words: beef, modified distillers grains, fatty acids, marbling. 


\section{INRODUCTION}

Over the last 10 years a significant increase in ethanol production in the U.S. has occurred, from 2.1 billion gallons in 2002 to 9 billion in 2008 (Renewable Fuels Association, 2009). Consequently, a greater supply of distillers byproduct has been available for cattle feeding. During milling, starch is removed from the grain and hydrolyzed to dextrin by an $\alpha$ amylase enzyme. Dextrin is converted into glucose by glucoamylase sugar, and yeast species such as Saccharomyces cerevisiae convert glucose into ethanol and $\mathrm{CO}_{2}$ (Davis, 2001). After fermentation, the whole stillage is centrifuged and coarser particles generate wet distillers grains (WDG) or dried distillers grains (DDG). When drying, the coarser fraction usually passes through a rotary dryer. The remaining liquid fraction is condensed, producing solubles (S). The solubles may be added back to WDG or DDG to form WDGS or DDGS, respectively (Stock et al., 2000). Modified distillers grains plus solubles (MDGS), are obtained through partial drying until achieving moisture levels of 50 to $54 \%$.

The final concentration of protein and fat are increased in ethanol byproducts (Klopfenstein et al., 2007). Research conducted at the University of Nebraska has shown that feeding WDGS or DDGS combined with corn improves growth, reproduction, carcass traits, and cattle performance (Lodge et al., 1997; Martin et al., 2007; and Corrigan et al., 2009). However, little research has been conducted to quantify the effects of feeding MDGS on beef quality. Vander Pol et al. (2009) suggested that some fat in distillers grains may be protected from rumen biohydrogenation, which may increase the concentration of unsaturated fatty acid at the duodenum. These fatty acids may be absorbed and later deposited in the lean. Therefore, in this study we hypothesized that feeding MDGS could alter the fatty acid profile of beef. The aim of this work was to identify the effects of feeding MDGS on beef fatty acid percent. 


\section{MATERIAL AND METHODS}

All procedures related to live animals for this study were approved by the Institutional Animal Care and Use Committee of the University of Nebraska-Lincoln.

\section{Animal, Diets, and Sample Collection}

Yearling $(\mathrm{n}=268)$ Angus crossbred steers were randomly allocated to 36 pens, which were assigned randomly to six treatments (Table 1) containing high-moisture corn, dry-rolled corn, and different levels of MDGS (0, 10, 20, 30, 40, or 50\% MDGS - DM basis). Although animals were fed by pen, the experimental unit in this work was the animal due to sampling conditions at the commercial plant. As levels of MDGS increased acroos the treatments, the ratio of dry-rolled corn and high moisture corn (1:1) decreased. Diets included 7.5\% of alfalfa hay and 5\% of supplement. Additionally, Rumensin (Elanco Animal Health) at 320 mg, Tylan (Elanco Animal Health) at $90 \mathrm{mg}$ and thiamine at $150 \mathrm{mg}$ per steer were supplemented daily. and implanted at day 1 and 67 with Synovex ${ }^{\circledR}$ Choice (Fort Dodge Animal Health). Steers were fed $176 \mathrm{~d}$ and implanted at day 1 and 67 with Synovex ${ }^{\circledR}$ Choice (Fort Dodge Animal Health) prior to slaughter and transferred to a commercial abattoir. Fourty-eight h postmortem, marbling attributes (score, texture, and distribution) were evaluated by a USDA beef carcass grading supervisor. After grading, a 7 mm-thick slice of the LM was collected at the $12^{\text {th }} / 13^{\text {th }}$ rib region from each carcass to analyze the fatty acid profile and proximate composition. Ribeye slices were transferred under refrigeration to the University of Nebraska Meat Laboratory trimmed of subcutaneous fat and connective tissue, vaccum packaged and stored at $-35^{\circ} \mathrm{C}$. Prior to both analyses, samples were pulverized with liquid nitrogen $\left(-174^{\circ} \mathrm{C}\right)$ using a blender (Waring Commercial, model 51BL32, Torring, CT), and stored at $-80^{\circ} \mathrm{C}$ until the fatty acid analysis and proximate analysis could be completed.

PROXIMATE AND FATTY ACID ANALYSES 
Fatty acid profiles were analyzed according to Folch et al. (1957), Morrison and Smith (1964), and Metcalfe et al. (1966). Fatty acids were isolated from the lipid portion of the lean. One gram of pulverized sample was weighed out in a $40 \mathrm{~mL}$ conical tube and $5 \mathrm{~mL}$ of 2:1 chlorofrom:methanol ( $\mathrm{v} / \mathrm{v})$ was added. The sample was homogenized for $5 \mathrm{~s}$ and allowed to stand for $1 \mathrm{~h}$ at room temperature. The homogenate was filtered through filter paper (Whatman \#2) into a 13 x $150 \mathrm{~mm}$ screw tube, the final volume was brought to $10 \mathrm{~mL}$ with chlorofrom:methanol, and then homogenized for $5 \mathrm{~s}$ with $2 \mathrm{~mL}$ of $0.74 \% \mathrm{KCl}$. Samples were centrifuged at $1000 \mathrm{x}$ g for $5 \mathrm{~min}$, the top layer phase was aspirated, and tubes were dried under nitrogen at $60^{\circ} \mathrm{C}$. After drying, samples were homogenized for $5 \mathrm{~s}$ with $0.5 \mathrm{~mL}$ of $0.5 \mathrm{M} \mathrm{NaOH}$ in methanol and heated for $5 \mathrm{~min}$ at $100^{\circ} \mathrm{C}$. Following heating, $0.5 \mathrm{~mL}$ of $\mathrm{BF}_{3}$ in $14 \%$ methanol was added into the tubes which were homogenized for $5 \mathrm{~s}$ and reheated at $100^{\circ} \mathrm{C}$. Samples were homogenized with saturated salt solution $(\mathrm{NaCl})$ and $1 \mathrm{~mL}$ of hexane for $5 \mathrm{~s}$ and centrifuged at $1000 \mathrm{x} g$ for $5 \mathrm{~min}$. After centrifuging, an aliquot of the top layer containing the fatty acid methyl esters was transferred to vials which were purged and capped with nitrogen prior to Gas Chromatography analysis (Hewlett-Packard Gas Chromatograph - Agilent Technologies, model 6890 series, CA, USA). Individual fatty acids were separated using a capillary column [Chrompack CP-Sil $88(0,25 \mathrm{~mm} \times 100 \mathrm{~m})$ ] and identified through retention time according to known standards (NuChek Prep (Elysian, MN) fatty acid methyl ester standards no. 68D, 79, 87 and 458). Temperature of the oven was set to increase from 140 to $220^{\circ} \mathrm{C}$ at $2^{\circ} \mathrm{C} / \mathrm{min}$ and held at $220^{\circ} \mathrm{C}$ for $20 \mathrm{~min}$. Simultaneously, injector and detector temperatures were maintained at 270 and $300^{\circ} \mathrm{C}$, respectively, and compounds were carried by He at a flow rate of $1.0 \mathrm{~mL} / \mathrm{min}$.

Values of moisture and ash (\%) were quantified by a LECO Thermogravimetric Analyzer (LECO Corporation, model 604-100-400, MI, USA). Moisture analysis was performed on N 
atmosphere where the ramp rate was set at $6 \% \mathrm{~m}$, ramp time at $17 \mathrm{~min}$, start temperature at $25^{\circ} \mathrm{C}$, and end temperature at $130^{\circ} \mathrm{C}$. Ash analysis was performed on Oxygen atmosphere where the ramp rate was set at $20 \mathrm{~d} / \mathrm{m}$, ramp time at $30 \mathrm{~min}$, start temperature at $130^{\circ} \mathrm{C}$ and end temperature at $600^{\circ} \mathrm{C}$. For both moisture and ash analyses, flow rate, hold time, constant weight and constant weight time were set at high, $0 \mathrm{~min}, 0.05 \%$ and $9 \mathrm{~min}$ respectively. The crucible density was set at 3 and sample density at 1 . Fat content was determined by ether extraction using the Soxhlet procedure (AOAC, 1990). Two grams of powdered samples were weighed out in a filter paper (Whatman \#2) envelope and lipids were extracted using ether as the solvent.

Marbling, fatty acids and proximate analysis were analyzed as a complete randomized design where dietary treatment was the main effect. In this experiment, the animal was used as experimental unit. Linear and quadratic relationships were detected by response curves. Linear relationships between marbling and fat content were analyzed using the REG procedure and data were analyzed using the GLIMMIX procedure of SAS ${ }^{\circledR}$ (Version 9.2, Cary, N.C., 2007). When significance $(P \leq 0.05)$ was indicated by ANOVA, means separations were performed using the LSMEANS and DIFF functions.

\section{RESULTS AND DISCUSSION}

\section{MARBLING ATTRIBUTES AND PROXIMATE VALUES}

Dietary treatments did not alter marbling score, marbling distribution, fat or ash (Table

2). A quadratic relationship was detected for moisture content. For marbling texture, there was a significant interaction between dietary treatment and USDA grade $(P=0.02)$. Carcasses graded USDA Choice had significantly coarser marbling texture than USDA Select carcasses from steers fed 0, 10, 20, 40, and 50\% MDGS. Regarding treatments, although a significant interaction was observed, there was no consistent pattern to indicate an optimum level of MDGS 
for marbling texture. Statistically, the individual $P$ value of dietary treatment was 0.35 whereas for grade it was $<0.01$. Thus, it appears that feeding MDGS had minimal effects on marbling texture due to its individual high $P$ value. Except for 20\% MDGS, all treatments showed significant linear relationships between marbling score and fat content $(P \leq 0.05)$ (Table 3$)$ and the test of common slopes revealed that all of them were similar (0.45) (Figure 1). Fat content of ribeyes vary from $7.43 \%$ to $8.68 \%$. Considering that beef fat contains $8.5 \%$ of trans fat, important implications for human health and labeling may be an important issue since increased levels of trans fat per serving may be found.

As described previously, MDGS is very low in starch. When feeding grain, more propionate is produced in the rumen. The propionate can be converted to glucose and is correlated to marbling deposition (Smith and Crouse, 1984). Feedstuffs that are low in starch and contain more fiber are used in the rumen to yield more acetate, which is a precursor for subcutaneous fat deposition (Smith and Crouse, 1984). Modified wet distillers grains plus solubles contain more protein, fat, and fiber compared to corn (Klopfenstein et al., 2007). Therefore, we would expect significant differences in marbling through feeding MDGS. However, this study showed that levels up to 50\% did not alter marbling attributes. Similar results were observed by Larson et al. (1993) and Lodge et al. (1997) when feeding wet distillers grains regarding quality grade. Vander Pol et al. (2009) showed that feeding distillers grains stimulated greater propionate production in the rumen than corn. They attribute this effect to the soluble. Corrigan et al. (2009) also showed that the inclusion of 40\% of WDGS in diets containing dry rolled corn, high moisture corn, and steam-flaked corn led to higher levels of propionate and a lower acetate:propionate ratio in the rumen when compared to diets with no 
addition of WDGS. Additionally, Russell (1998) showed that disitillers byproducts may change the ruminal $\mathrm{pH}$, which influence the ratio of acetate:propionate.

Klopfenstein et al. (2008), summarizing different experiments, showed quadratic responses of ADG, G:F, and DMI as levels of WDGS increased in feedlot diets. Likewise, our experiment showed a quadratic relationship for fat content with optimal levels varying from 20 to $40 \%$. Feeding levels above $45 \%$ may compromise HCW and ribeye area (Depenbush et al., 2009). It seems that optimal levels of distillers grains in diets vary from 20 to $40 \%$.

\section{FATTY ACIDS}

Individual fatty acid percent are presented in Table 4. For 18:1 trans, we did not separate the isomers. Feeding MDGS did not affect percent of hexanoic (6:0), decanoic (10:0), lauric (12:0), myristic (14:0), isostearic (iso 18:0), homogamma linolenic (20:3, n-6) and arachidonic (20:4, n-6) fatty acids.

As levels of MDGS increased, a linear decrease of myristoleic (14:1, n- 5), pentadecanoic (15:0), palmitic (16:0), heptadecanoic (17:0), oleic (18:1, n-9), and docosapentaenoic (22:5, n-3) was observed (Table 4). A similar pattern was observed in all n-7 fatty acids. On the other hand, a linear increase in stearic (18:0), 18:1 trans isomers (trans-6-8-Octadecenoic acid, 6-8t, elaidic acid, 9t, trans-10-Octadecenoic acid, 10t, and trans vaccenic, 11t), linoleic (18:2, n-6), linolenic (18:3, n-3), nonadecanoic (19:0), and eicosanoic (20:0) was observed as levels of MDGS increased in the diets. In future studies, the identification of individual 18:1 trans fatty acid isomers may be useful to understand different potential health effects.

Similarly, CLA isomers (trans 7, cis 9-18:2 and cis 9, trans 11-18:2) increased linearly in the muscle as diets contained higher levels of byproduct. 
Values of isopalmitic (iso 16:0) differed among the treatments $(P<0.01)$ and a quadratic trend was observed as MDGS levels increased $(P=0.09)$. For linoelaidic $(18: 2$ trans $)$, a quadratic relationship was detected due to a slight decrease of this fatty acid in beef from animals fed 50\% MDGS. Although there was no difference among the treatments for CLA 18:2, trans 10, cis 12, a quadratic response in order of the increase of MDGS were observed. Looking at total trans percent, a cubic relationship was highly significant. However a quadratic response explained better the responses of total trans fatty acids to MDGS. Cubic relationships were observed for eicosenoic (20:1, n-9), and total SFA, however, treatments did not statistically differ in SFA. As levels of MDGS increased, percent of PUFA and n-6 fatty acids linearly increased. No effects of dietary treatment were observed in percent of n-3 fatty acids.

Triglycerides are biohydrogenated in the rumen by microbial lipases produced by bacteria releasing the fatty acids (Jenkins, 1993). Likely, the effects of MDGS inclusion in finishing diets on fatty acids percent in this work are due to the greater amount of fatty acids from this feedstuff that are biohydrogenated in the rumen (Vander Pol et al., 2009). It is known that fatty acids reaching the duodenum originate directly from diets and microbial transformation (Jenkins et al. 2008). After lipid hydrolysis, unsaturated fatty acids are converted to SFA through isomerization forming trans fatty acids intermediates including CLAs, which have their double bonds hydrogenated (Harfoot and Hazlewood, 1988). This explains the higher levels of total trans fatty acids in beef from animals fed 30 to 50\% MDGS since the conversion of the linoleic at the beginning of the hydrogenation may be increased due to high digestibility of MDGS fat when compared to other fat sources. Additionally, Chin et al. (1992) affirmed that one of the most important CLA sources is lipid from ruminants. However in this work, very small percent of CLA were found in the muscle. This may be happened during methylation where the acidic 
conditions could convert the CLA's to trans fatty acids or methoxy artifacts. However, during sample preparation all subcutaneous fat were removed from the sample. Jiang et al. (2010) showed that CLAs are found in greater percent in subcutaneous than intramuscular fat, therefore, lower values of CLAs in samples containing only lean tissue would be expected. As discussed previously, the fat digestibility of this feedstuff is higher than corn, generating larger percent of intermediates such as the CLA 18:2, cis 9, trans 11 during biohydrogenation. French et al. (2000) showed that the absorption of CLA from the gastrointestinal tract and amount of linoleic acid at the duodenum may affect the CLA absorption through changing the growth and activity of Butyrivibrio fibrisolvenses. This would explain a linear increase of this fatty acid in beef from animals fed 50\% MDGS. Additionally, beef from cattle fed high fiber has higher CLA concentration when compared to corn (French et al., 2000). This is in agreement with feeding MDGS, which contain more fiber than corn. Linoleic and linolenic acids are the main UFA in ruminat diets (Woods and Fearon, 2009). During biohydrogenation, Wood et al. (1963) observed that after $48 \mathrm{~h}$ in the rumen, linoleic acid is converted to stearic (46\%), oleic or 18:1 trans (33 to 50\%), and 3 to 6\% remained as linoleic. Additionally, Ward et al. (1964) reported that linolenic acid is rapidly hydrogenated in the rumen environment, generating linoleic, oleic and stearic acids. They reported that $93 \%$ of all intermediates linoleic acid are converted to stearic and a small accumulation of 18:1 trans can be found. In this work, all these three fatty acids increased linearly in lean tissue as levels of MDGS increased indicating that this conversion was optimized by feeding higher levels of MDGS. Vander Pol et al. (2009) found higher percent of of total 18:1 trans, oleic, and linoleic reaching the duodenum in WDGS fed cattle when compared to corn fed. The absorption of these fatty acids depends of the surface area of bile salt micelles, which may be enhanced by the presence of unsaturated fatty acids (Zinn et al., 2000). This explains the 
linear increase in PUFA, n-6, and n-6: n-3 ratio as levels of MDGS increased in finishing diets. Lock et al. (2005) affirmed that the digestibility of fatty acids decreases as chain length and number of double bonds increase. In the present study, a linear decrease of docosapentaenoic acid was observed as MDGS levels increased.

Regarding the n-7 fatty acids, it appears that the higher digestibility of MDGS fat when compared to corn may have altered the biohydrogenation pathways decreasing the ability of the rumen bacteria to reduce these fatty acids. Consequently, the absorption and transportation of these fatty acids from the small intestine to the lean did not occur to the same extent as when animals are corn-fed.

Results and trends presented in this study regarding decanoic, lauric, myristic, pentadecanoic, palmitoleic, heptadecanoic, linoleic, CLA 18:2, cis 9, trans 11, total PUFA, and n-6: n-3 ratio are similar to results presented by Depenbush et al. (2009). Additionally, similar results regarding n-6 and omega 6:omega 3 were found by Gill et al. (2008) when comparing distillers grains to steam-flaked corn. Apparently, corn based distillers grains affect the fatty acid profile of beef differently compared to wheat-based distillers grains. Shand et al. (1998) found no effect on fatty acid profile in beef when feeding wheat-based distillers grains and wet brewers grains compared to corn, possibly due to the lower fat concentration of wheat (27\%) when compared to corn (47\%).

An increase of total trans fatty acids in beef from animals fed higher levels of MDGS was observed in this study. Grundy (1994) and Semma (2002) presented results where trans fatty acids and palmitic acid increased the low density lipoprotein (LDL) cholesterol and decreased the high density lipoprotein (HDL) cholesterol in human blood. Gould et al. (1998) showed that 
LDL cholesterol may harm human health through the development of arthrosclerosis and subsequent coronary heart disease. However, Wahle et al. (2004) presented a series of studies reporting health benefits of CLAs such as anti-cancer, anti-atherosclerosis, anti-inflammatory, and anti-obesity properties, as well as capacity of enhancing antibody formation. The increase of stearic acid in beef as MDGS increased in the diets does not represent a potential risk for human health since this fatty acid does not or minimally affects total cholesterol (Kris-Etherton et al., 1993; Judd et al., 2002).

Jenschke et al. (2007), showed that there is a negative relationship between beef liver off-flavor and levels of cis vaccenic. Therefore, lower levels of this fatty acid may affect beef palatability.

In this study we observed higher percent of n-6 fatty acids, and n-6: n-3 ratio in beef from steers fed MDGS when compared to beef from corn-fed cattle. Simopoulos (2002) suggested that elevated levels of these fatty acids and elevated ratio may cause cardiovascular disease, cancer, inflammatory and autoimmune diseases. This could be minimized by higher levels of n-3, but no changes in these fatty acids were observed.

\section{CONCLUSION}

Feeding MDGS increased PUFA, total trans, n-6 fatty acids, n-6: n-3 ratio and decreased palmitic acid in beef. Athough the increase of PUFA may decrease lipid stability in meat, the change in fatty acid profile caused by feeding MDGS does not represent a risk to human health.

\section{REFERENCES}

Burdge G. C. and Wootton S. A. 2002. Conversion of alpha-linolenic acid to eicosapentaenoic, docosapentaenoic and docosahexaenoic acids in young women. Br. J. Nutr. 88:411-420. 
Chin, S. F., W. Liu, J. M. Storkson, Y. L. Ha, and W. M. Pariza. 1992. Dietary sources of conjugated dienoic isomers of linoleic acid, a newly recognized class of anticarcinogens. J. Food Compos. Anal. 5:185-197.

Corrigan, M. E., G. E. Erickson, T. J. Klopfenstein, M. K. Luebbe, K. J. Vander Pol, N. F. Meyer, C. D. Buckner, S. J. Vanness, and K. J. Hanford. 2009. Effect of corn processing method and corn wet distillers grains plus solubles inclusion level in finishing steers. J. Anim. Sci. 87: 3351-3362.

Davis, K. S. Corn Milling, Processing and Generation of Co-products. 2001. Minnesota Nutrition Conference, Technical Symposium. 2001. Available at: http://www.ddgs.umn.edu/articlesproc-storage-quality/2001-Davis-\%20Processing.pdf. Accessed on 10/02/09.

Depenbusch, B. E., C. M. Coleman, J. J. Higgins, and J. S. Drouillard. 2009. Effects of increasing levels of dried corn distillers grains with solubles on growth performance, carcass characteristics, and meat quality of yearling heifers. J. Anim. Sci. 87:2653-2663.

Folch, J., M. Lees, and G. H. S. Stanley. 1957. A simple method for the isolation and purification of total lipids from animal tissues. J. Biol. Chem. 226:497-509.

French P., C. Stanton, F. Lawless, E. G. O'Riordan, F. J. Monahan, P. J. Caffrey, and A. P. Moloney. 2000. Fatty acid composition, including conjugated linoleic acid, of intramuscular fat from steers offered grazed grass, grass silage, or concentrate-based diets. J. Anim. Sci. 78:2849-2855.

Gill, R. K., D. L. VanOverbeke, B. Depenbusch, J. S. Drouillard, and A. DiCostanzo. 2008. Impact of beef cattle diets containing corn or sorghum distillers grains on beef color, fatty acid profiles, and sensory attributes. J Anim. Sci. 86:923-935. 
Gould, A. L., J. E. Rossouw, N. C. Santanello, J. F. Heyse, C. D. Furberg. 1995. Cholesterol Reduction Yields Clinical Benefit: A New Look at Old Data. Circulation. 91:2274-2282

Grundy S. M. 1994. Influence of stearic acid on cholesterol metabolism relative to other longchain fatty acids. Am. J. Clin. Nutr. 60 (Suppl):986-990.

Harfoot, C. G., and G. P. Hazlewood. 1988. Lipid metabolism in the rumen. Pages 285-322 in The Rumen Microbial Ecosystem. Elsevier Science Publishing, New York, NY.

Martin, J. L., A. S. Cupp, R. J. Rasby, Z. C. Hall, and R. N. Funston. 2007. Utilization of dried distillers grains for developing beef heifers. J. Anim. Sci. 85:2298-2303.

Jenkins, T. C., R. J. Wallace, P. J. Moate, E. E. Mosley. BOARD-INVITED REVIEW: Recent advances in biohydrogenation of unsaturated fatty acids within the rumen microbial ecosystem. J. Anim. Sci. 2008 86: 397-412.

Jenkins. T. C. Lipid metabolism in the rumen. 1993. J. Dairy Sci. 76:3852-3863.

Jenschke, B. J., J.M. Hodgen, J.L. Meisinger, A.E. Hamling, D.A. Moss, M. Lundesjö Ahnström, K.M. Eskridge, and C.R. Calkins. 2007. Unsaturated fatty acids and sodium affect the liverlike off flavor in cooked beef J. Anim. Sci. 85:3072-3078.

Jiang, T., J.R. Busboom , M.L. Nelson , J. O’Fallon , T.P. Ringkob , D. Joos , K. Piper. 2010. Effect of sampling fat location and cooking on fatty acid composition of beef steaks. Meat Sci. 84: 86-92

Judd, J. T., D. J. Baer, B. A. Clevidence, P. Kris-Etherton, R. A. Muesing, and M. Iwane. 2002. Dietary cis and trans monounsaturated and saturated FA and plasma lipids and lipoproteins in men. Lipids. 7:123-31. 
Klopfenstein, T. J., G. E. Erickson, V. R. Bremer. 2008. BOARD-INVITED REVIEW: Use of distillers by-products in the beef cattle feeding industry. J. Anim. Sci, 86:1223-1231.

Kris-Etherton P. M., J. Deer, D. C. Mitchell, V. A. Mustad, M. E. Russell, E. T. McDennell, D. Slabsky, T. A. Pearson. 1993. The role of fatty acids saturation on plasma lipids, lipoproteins: I. Effects of whole food diets high in cocoa butter, olive oil, soybean oil, dairy butter, and milk chocolate on the plasma lipids of young men. Metabolism 42:121-129.

Larson, E.M., R. A. Stock, T. J. Klopfenstein, M. H. Sindt, and R. P. Huffman. 1993. Feeding value of wet distiller’s byproducts. J. Anim. Sci. 71:2228-2236

Lock, A. L., K. J. Harvatine, I. I. Ipharraguerre, M. Van Amburgh, J. K. Drackley, and D. E. Bauman. 2005. The dynamics of fat digestion in lactating dairy cows: What does the literature tell us? Proc. Cornell Nutr. Conf. 83-94.

Lodge S. L., R. A. Stock, T. J. Klopfenstein, D. H. Shain, and D. W. Herold. 1997. Evaluation of corn and sorghum distillers byproducts. J. Anim. Sci. 75:37-43.

Metcalfe, L.D., A.A. Schmitz, and J.R. Pelka. 1966. Rapid preparation of fatty acid esters from lipids for gas chromatographic analysis. Anal. Chem. 38:514-515.

Morrison, W.R., and L.M. Smith. 1964. Preparation of fatty acid methyl esters and dimethylacetals from lipids with boron fluoride-methanol. J. Lipid Res. 5:600-608.

Nestel P., P. Clifton, and M. Noakes. 1994. Effects of increasing dietary palmitoleic acid compared with palmitic and oleic acids on plasma lipids of hypercholesterolemic men. J. Lipid Res.35: 656-662.

Renewable Fuels Association. (2009). Statistics. http://www.ethanolrfa.org/industry/statistics Accessed Oct. 5, 2009. 
Russell, J. B. 1998. The importance of $\mathrm{pH}$ in the regulation of ruminal acetate to propionate ratio and methane production in vitro. J. Dairy Sci. 81:3222-3230.

Semma, M. 2002. Trans Fatty Acids: Properties, Benefits and Risks. J. Health Sci. 48:7-13.

Shand, P. J., J. J. McKinnon, and D.A. Christensen. 1998. Eating quality of beef from animals fed wet brewers’ grains and wheat-based wet distiller’s' grains. Can. J. Anim. Sci. 78:143146.

Simopoulos, A. P. 2002. The importance of the ratio of omega-6/omega-3 essential fatty acids.

Bio. Pharm. 56:365-79.

Smith, S. B. and J. D. Crouse. 1984. Relative contributions of acetate, lactate and glucose of lipogenesis in bovine in muscular and subcutaneous adipose tissue. J. Nutr. 114:792-800.

Stock, R. A., J. M. Lewis, T. J. Klopfenstein, and C. T. Milton. (2000). Review of new information on the use of wet and dry milling feed by-products in feedlot diets. J. Anim. Sci. 78 (E-Suppl.). http://www.asas.org/symposia/9899proc/0924.pdf. Accessed July 3, 2007.

Vander Pol, K., M. Luebbe, G. I. Crawford, G. E. Erickson, and T. J. Klopfenstein. 2009. Performance and digestibility characteristics of finishing diets containing distillers grains, composites of corn processing coproducts, or supplemental corn oil. J. Anim. Sci. 87: 639652.

Wahle, K. W. J., S. D. Heys, D. Rotondo. 2004. Conjugated linoleic acids: are they beneficial or detrimental to health? Prog. in Lipid Res. 43:553-587

Ward, P. F. V., T. W. Scott, and R. M. C. Dawson. 1964. The hydrogenation of unsaturated fatty acids in the ovine digestive tract. Biochem. J. 92:60-68. 
Wood, R. D., M. C. Bell, R. B. Grainger, and R. A. Teekel. 1963. Metabolism of labeled linoleic-1-14C acid in the sheep rumen. J. Nutr. 79:62-68.

Woods, V. B., and Fearon, A. M. 2009. Dietary sources of unsaturated fatty acids for animals and their transfer into meat, milk and eggs: A review. Livestock Sci. 126:1-20.

Zinn R. A., S. K. Gulati, A. Plascencia, and J. Salinas. 2000. Influence of ruminal biohydrogenation on the feeding value of fat in finishing diets for feedlot cattle. J. Anim. Sci. 78:1738-1746. 
Table 1. Dietary treatments composition (\%DM basis).

\begin{tabular}{lcccccc}
\hline & \multicolumn{5}{c}{ Treatments (\% MDGS) } \\
\cline { 2 - 6 } Ingredients & $\mathbf{0}$ & $\mathbf{1 0}$ & $\mathbf{2 0}$ & $\mathbf{3 0}$ & $\mathbf{4 0}$ & $\mathbf{5 0}$ \\
\hline Dry rolled corn & 41.25 & 38.75 & 33.75 & 28.75 & 23.75 & 18.75 \\
High moisture corn & 41.25 & 38.75 & 33.75 & 28.75 & 23.75 & 18.75 \\
MDGS & 0 & 10 & 20 & 30 & 40 & 50 \\
Alfalfa & 7.5 & 7.5 & 7.5 & 7.5 & 7.5 & 7.5 \\
Molasses & 5 & 0 & 0 & 0 & 0 & 0 \\
Mineral and vitamin supplement & 5 & 5 & 5 & 5 & 5 & 5 \\
\hline
\end{tabular}


Table 2. Marbling attributes and proximate values of ribeye slices (Longissiumus thoracis) from steers fed modified distillers grains plus solubles (MDGS, \%).

\begin{tabular}{|c|c|c|c|c|c|c|c|c|c|c|c|}
\hline \multirow[b]{2}{*}{ Attributes and prox. values } & \multicolumn{6}{|c|}{ Dietary treatments (\%MDGS - DM basis) } & \multirow[t]{2}{*}{ S.E.M. ${ }^{1}$} & \multirow[t]{2}{*}{$P$ - value } & \multicolumn{3}{|c|}{ Contrasts $^{2}$} \\
\hline & $\mathbf{0}$ & 10 & 20 & 30 & 40 & 50 & & & Linear & Quadratic & Cubic \\
\hline Marbling score $^{3}$ & Slight $^{93}$ & Slight $^{93}$ & Small $^{02}$ & Small $^{01}$ & Slight $^{95}$ & Slight $^{93}$ & 6.09 & 0.76 & 0.13 & 0.14 & 0.93 \\
\hline Marbling distribution $^{4}$ & 1.12 & 1.20 & 1.13 & 1.17 & 1.22 & 1.21 & 0.06 & 0.71 & 0.12 & 0.83 & 0.76 \\
\hline Marbling texture ${ }^{5}$ Choice & $1.74^{\mathrm{Aa}}$ & $1.65^{\text {Аа }}$ & $1.67^{\mathrm{Aa}}$ & $1.42^{\mathrm{B}}$ & $1.91^{\mathrm{Aa}}$ & $1.44^{\mathrm{Ba}}$ & 0.09 & $0.02 *$ & 0.41 & 0.91 & 0.14 \\
\hline Marbling texture ${ }^{5}$ Select & $1.11^{\mathrm{b}}$ & $1.23^{\mathrm{b}}$ & $1.18^{\mathrm{b}}$ & 1.24 & $1.08^{\mathrm{b}}$ & $1.15^{\mathrm{b}}$ & 0.09 & $0.02 *$ & 0.75 & 0.37 & 0.36 \\
\hline Fat, \% & 7.43 & 7.95 & 8.68 & 8.61 & 8.11 & 8.03 & 0.39 & 0.18 & 0.67 & 0.02 & 0.65 \\
\hline Moisture, \% & 71.58 & 71.09 & 70.52 & 70.38 & 70.91 & 71.19 & 0.30 & 0.06 & 0.74 & $<0.01$ & 0.95 \\
\hline Ash, \% & 1.72 & 1.67 & 1.85 & 1.79 & 1.67 & 1.56 & 0.11 & 0.57 & 0.50 & 0.19 & 0.48 \\
\hline
\end{tabular}

${ }^{1}$ Standard error of the mean.

${ }^{2}$ Linear, quadratic, and cubic responses to MDGS level.

${ }^{3}$ Slight $=300$, and Small $=400$.

${ }^{4}$ Even $=1$, Uneven $=2$.

${ }^{5}$ Fine $=1$, Medium $=2$, Coarse $=3$.

${ }^{\mathrm{A}, \mathrm{B}}$ Means in the same row having different superscripts are significant at $P=0.02$ within marbling texture.

${ }^{\mathrm{a}, \mathrm{b}}$ Means in the same column having different superscripts are significant at $P=0.02$ within marbling texture.

$* P$ - value for the interaction between dietary treatment and USDA quality grade. 
Table 3. Linear relationships between marbling and fat content (\%) ribeye slices (Longissiumus thoracis) from steers fed modified distillers grains plus solubles (MDGS, \%).

Treatments (\% MDGS, DM basis) Marbling equations

\begin{tabular}{cccc}
0 & $306.47+12.49 \mathrm{fat}$ & $<0.01$ & 0.18 \\
10 & $258.48+17.01 \mathrm{fat}$ & $<0.01$ & 0.30 \\
20 & $348.57+8.39 \mathrm{fat}$ & 0.10 & 0.07 \\
30 & $310.60+9.51 \mathrm{fat}$ & $<0.01$ & 0.19 \\
40 & $293.00+12.26 \mathrm{fat}$ & $<0.01$ & 0.21 \\
50 & $326.45+6.86 \mathrm{fat}$ & 0.04 & 0.10 \\
\hline
\end{tabular}


Table 4. Weight percentage of fatty acids ${ }^{1}$ of ribeye slices (Longissimus thoracis) from steers fed modified distillers grains plus solubles (MDGS, \%).

Dietary treatments (\%MDGS - DM basis)
Fatty Acid

6:0 - hexanoic

10:0 - decanoic

12:0 - lauric

14:0 - myristic

14:1(n- 5) - myristoleic

15:0 - pentadecanoic

iso16:0 - isopalmitic

16:0 - palmitic

17:0 - heptadecanoic

17:1(n- 7) - heptadecenoic

Iso18:0 - isostearic

18:0 - stearic

18:1 trans $^{4}$

18:1(n-9) - oleic

18:1(n- 7) - cis vaccenic

18:2 trans - linoelaidic

18:2(n-6) - linoleic

CLA 18:2, cis 9, trans 11

CLA 18:2, trans 10, cis 12

18:3(n-3) - linolenic

19:0 - nonadecanoic

20:0 - eicosanoic

20:1(n-9) - eicosenoic

20:3(n-6) - homogamma linolenic

20:4(n-6) - arachidonic

22:5(n-3) - docosapentaenoic 16:1(n- 7) - palmitoleic

\begin{tabular}{|c|c|c|}
\hline 0 & 10 & \\
\hline 0.22 & 0.22 & \\
\hline 0.005 & 0.01 & \\
\hline 0.02 & 0.02 & \\
\hline 3.34 & 3.36 & \\
\hline $0.93^{\mathrm{a}}$ & $0.83^{b}$ & \\
\hline $0.55^{\mathrm{ab}}$ & $0.57^{\mathrm{a}}$ & \\
\hline $0.54^{\mathrm{ab}}$ & $0.55^{\mathrm{a}}$ & \\
\hline $26.00^{\mathrm{a}}$ & $25.46^{b}$ & 2 \\
\hline $3.37^{\mathrm{a}}$ & $3.12^{b}$ & \\
\hline $1.45^{\mathrm{a}}$ & $1.48^{\mathrm{a}}$ & \\
\hline $1.16^{\mathrm{a}}$ & $1.10^{\mathrm{a}}$ & \\
\hline 0.30 & 0.34 & \\
\hline $12.55^{\mathrm{d}}$ & $13.44^{\mathrm{C}}$ & 1 \\
\hline $4.43^{\mathrm{d}}$ & $4.96^{\mathrm{d}}$ & \\
\hline $36.45^{\mathrm{a}}$ & $35.76^{\mathrm{ab}}$ & 34 \\
\hline $2.33^{\mathrm{a}}$ & $1.95^{\mathrm{b}}$ & \\
\hline $0.06^{\mathrm{c}}$ & $0.07^{\mathrm{bc}}$ & \\
\hline $3.13^{\mathrm{d}}$ & $3.92^{c}$ & \\
\hline $0.000^{\mathrm{C}}$ & $0.000^{\mathrm{C}}$ & 0 \\
\hline 0.000 & 0.002 & \\
\hline $0.17^{\mathrm{b}}$ & $0.19^{\mathrm{ab}}$ & \\
\hline $0.005^{b}$ & $0.003^{b}$ & 0 \\
\hline $0.02^{\mathrm{b}}$ & $0.04^{\mathrm{ab}}$ & \\
\hline $0.50^{\mathrm{a}}$ & $0.44^{\mathrm{b}}$ & \\
\hline 0.13 & 0.13 & \\
\hline 0.53 & 0.60 & \\
\hline $0.05^{\mathrm{a}}$ & $0.04^{\mathrm{ab}}$ & 0 \\
\hline
\end{tabular}

$\begin{array}{ccc}\mathbf{3 0} & \mathbf{4 0} & \mathbf{5 0} \\ 0.20 & 0.20 & 0.21 \\ 0.02 & 0.02 & 0.01\end{array}$
S.E.M. ${ }^{2} \quad P$-value

Weight percentage values are

${ }^{2}$ Standard error of the mean.

${ }^{3}$ Linear, quadratic, and cubic responses to MDGS level.

${ }^{4}$ Includes trans-6-8-Octadecenoic acid, 6-8t, elaidic acid, 9t, trans-10-Octadecenoic acid, 10t, and trans vaccenic, 11t.

a,b,c,d Means in the same row having different superscripts are significant at $P \leq 0.05$.

$\begin{array}{llll}0.01 & 0.02 & 0.02 & 0.01\end{array}$

$\begin{array}{llll}3.25 & 3.21 & 3.20 & 3.15\end{array}$

0.006

0.84
0.18

$\begin{array}{llll}3.77^{\mathrm{bc}} & 0.77^{\mathrm{bc}} & 0.75^{\mathrm{bc}} & 0.71^{\mathrm{c}}\end{array}$

0.03

$<0.01$

$.54^{\mathrm{ab}} \quad 0.51^{\mathrm{bc}} \quad 0.52^{\mathrm{bc}} \quad 0.49^{\mathrm{c}}$

0.01

$<0.01$

0.26

0.02

$<0.01$

0.02

0.05

0.74

0.23

$<0.01$

$\begin{array}{ccc}0.02^{\mathrm{bc}} & 0.01^{\mathrm{c}} & 0.01^{\mathrm{c}} \\ \text { by Gas Chromatography. }\end{array}$

0.009

Contrasts $^{3}$

Linear Quadratic Cubic

$\begin{array}{ccccc}0.02 & 0.48 & 0.95 & 0.34 & 0.84 \\ 0.004 & 0.15 & 0.16 & 0.26 & 0.99\end{array}$

0.16

0.26

0.73

0.87

0.32

$<0.01$

$<0.01<0.01$

$<0.01<0.01 \quad 0.02$

$<0.01<0.01$

$<0.01<0.01$

$<0.01<0.01$

$0.46 \quad 0.06$

$<0.01<0.01$

$<0.01<0.01$

$<0.01<0.01$

$<0.01<0.01$

$<0.01<0.01$

$<0.01<0.01$

$<0.01<0.01$

0.03

$<0.01$

$<0.01$

0.02

0.62

0.29

0.45

$<0.01$

0.07

0.30

0.28

0.55

0.31

0.04

0.25

0.12

0.01

0.28

0.55

0.002

0.51

0.92

0.08

0.36

0.99

0.16
0.10

0.19

0.42

0.27

0.58

0.01

0.31

0.45

0.13

0.01

0.62

0.11

0.16

0.33

0.68

0.59

0.26

0.56

0.73

0.02

0.82

0.14
0.90

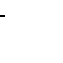


Table 5. Weight percentage of fatty acids ${ }^{1}$ groups of ribeye slices (Longissimus thoracis) from steers fed modified distillers grains plus solubles (MDGS, $\%)$.

\begin{tabular}{|c|c|c|c|c|c|c|c|c|c|c|c|}
\hline \multirow[b]{2}{*}{ Fatty Acids } & \multicolumn{6}{|c|}{ Dietary treatments (\%MDGS - DM basis) } & \multirow[t]{2}{*}{ S.E.M. ${ }^{2}$} & \multirow[t]{2}{*}{$P$ - value } & \multicolumn{3}{|c|}{ Contrasts $^{3}$} \\
\hline & $\mathbf{0}$ & 10 & 20 & 30 & 40 & 50 & & & Linear & Quadratic & Cubic \\
\hline SFA & 45.02 & 45.51 & 45.33 & 44.71 & 44.84 & 45.63 & 0.31 & 0.20 & 0.68 & 0.47 & 0.02 \\
\hline PUFA & $4.08^{\mathrm{d}}$ & $4.95^{\mathrm{c}}$ & $5.24^{\mathrm{c}}$ & $5.85^{\mathrm{b}}$ & $6.08^{\mathrm{b}}$ & $6.71^{\mathrm{a}}$ & 0.18 & $<0.01$ & $<0.01$ & 0.46 & 0.27 \\
\hline Total trans ${ }^{4}$ & $4.49^{\mathrm{d}}$ & $5.03^{\mathrm{d}}$ & $6.37^{\mathrm{c}}$ & $6.73^{\mathrm{c}}$ & $8.53^{\mathrm{a}}$ & $7.59^{\mathrm{b}}$ & 0.30 & $<0.01$ & $<0.01$ & 0.03 & $<0.01$ \\
\hline$n-3$ & 0.22 & 0.23 & 0.23 & 0.22 & 0.23 & 0.23 & 0.02 & 0.99 & 0.90 & 0.71 & 0.36 \\
\hline$n-6$ & $3.80^{\mathrm{d}}$ & $4.65^{c}$ & $4.90^{\mathrm{c}}$ & $5.50^{\mathrm{b}}$ & $5.72^{\mathrm{b}}$ & $6.37^{\mathrm{a}}$ & 0.18 & $<0.01$ & $<0.01$ & 0.55 & 0.28 \\
\hline$n-6: n-3$ & $16.07^{\mathrm{d}}$ & $19.20^{\mathrm{C}}$ & $21.08^{\mathrm{bc}}$ & $22.89^{\mathrm{ab}}$ & $23.22^{\mathrm{ab}}$ & $25.03^{\mathrm{a}}$ & 0.85 & $<0.01$ & $<0.01$ & 0.06 & 0.59 \\
\hline
\end{tabular}

${ }^{1}$ Weight percentage values are relative percent of all peaks observed by Gas Chromatography.

${ }^{2}$ Standard error of the mean.

${ }^{3}$ Linear, quadratic, and cubic responses to MWDGS level.

${ }^{4}$ Total trans fats includes trans-6-8-Octadecenoic acid, 6-8t, elaidic acid, 9t, trans-10-Octadecenoic acid, 10t, trans vaccenic, 11t, and the 18:2 trans isomers.

a,b,c,d Means in the same row having different superscripts are significant at $P \leq 0.05$. 


\section{Figure Caption}

Figure 1. Relationship between intramuscular fat and marbling score from steers fed modified distillers grains plus solubles (MDGS, \%). 


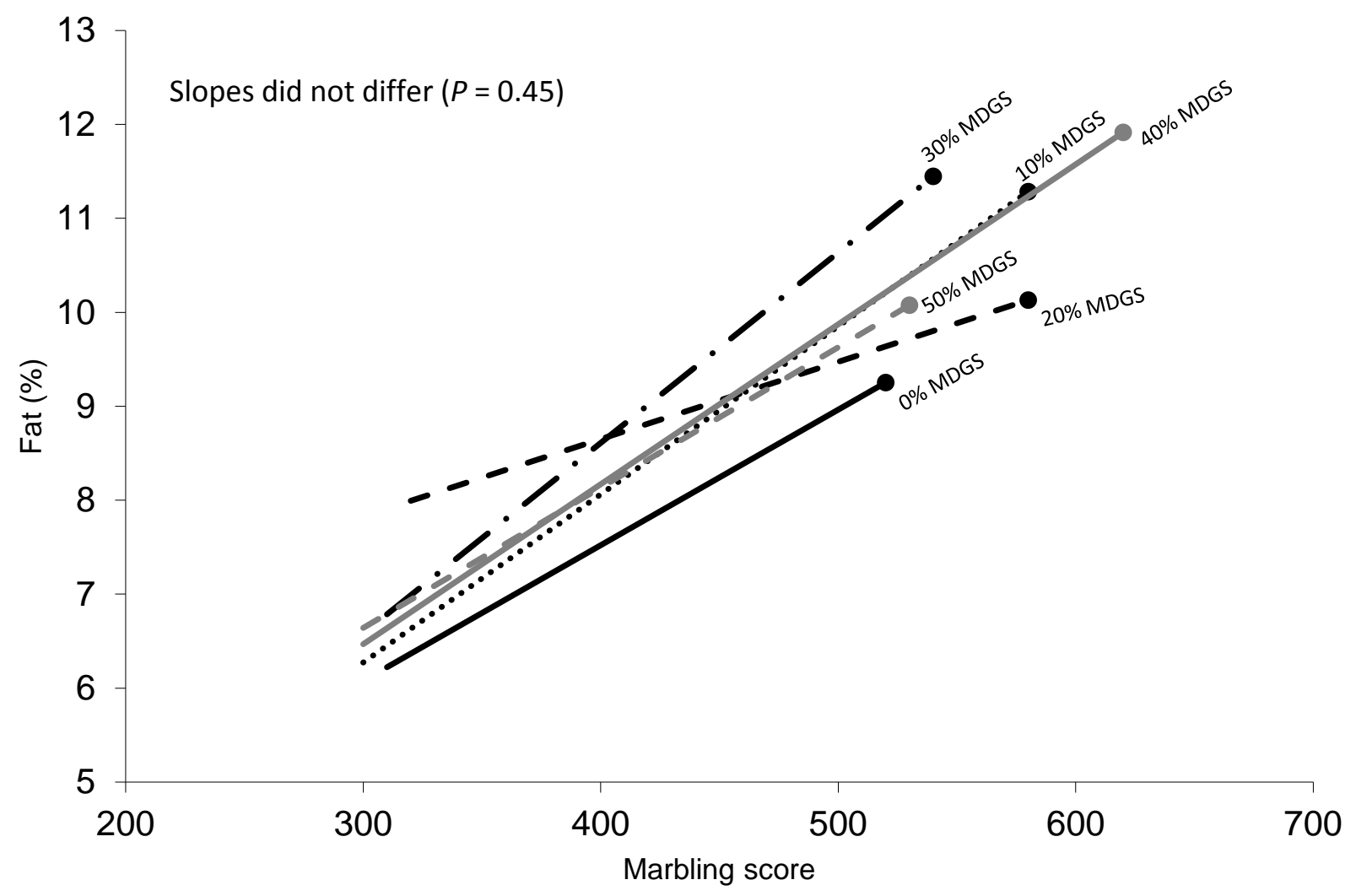

Figure 1 